UDC 741.52:81=111

$81 ' 373.612 .2=111$

Original scientific article

Accepted for publication on 11.09. 2019

https://doi.org/10.29162/jez.2019.9

\title{
Ilhana Škrgić
}

Independent researcher

\section{Figurative representation of death in the Italian comic book Dylan Dog}

The canonical representation of death as the Grim Reaper is a well-known trope in art. The main aim of this paper is to analyze this trope as it appears in selected instalments of the Italian comics series Dylan Dog. Fauconnier and Turner have extensively discussed its complexity by describing it in terms of the Blending Theory/Conceptual Theory model. As a complex integration of several mental spaces, including a space with an individual human being dying, and a harvest space, the Grim Reaper blend involves metaphoric and metonymic interactions of non-counterpart elements (Fauconnier \& Turner 1998). This model will be used as a starting point in the analysis of the corpus consisting of four separate Dylan Dog stories. In the selected issues, the Grim Reaper appears in both the traditional version: a skeleton-like creature dressed in a monk's robe and holding a scythe, as well as variants in which its appearance gains new and unusual characteristics. It will be demonstrated how the artists' use of the comics medium, with its combination of written text and static visuals, enables certain creative varieties on the classic trope.

Key words: metaphor; metonymy; blend; Death; Dylan Dog; comics; graphic novels. 


\section{Introduction}

This article aims to explore the visual representation of Death in the classic Italian horror comic book Dylan Dog, by utilizing Fauconnier and Turner's Conceptual Blending Theory, and in particular, their blend for the Grim Reaper, as a wellknown visual portrayal and personification of death in the collective consciousness of Western culture. The image of the Grim Reaper is especially dominant in visual arts and film, from its cinematic presence in Ingmar Bergman's The Seventh Seal (1957) to the section aptly titled "Death" in Monty Python's The Meaning of Life (1983).

At first glance, Dylan Dog is an unlikely subject of linguistic research. However, the medium of comic books in general (or graphic novels, as they are sometimes called $^{1}$ ) in recent years has provided a well of research topics for cognitive linguists and semioticians, ranging from visual representations of the idealized cognitive models of anger (Forceville 2003), to the exploration of the "visual narrative grammar" of the comic book form (Cohn 2013). Comic books are a unique combination of text and image; time and space are adequately presented without the moving image or sound articulation, and in that sense, this medium, referred to as the "ninth art", needs to be looked at from a new perspective, acknowledging its hybrid form and a high degree of abstraction (Wolk 2007: 14; Berninger et al. 2010: 2). It is precisely because of its unique medium-specific affordances that the medium of comics can convey meaning in creative ways: almost limitless visual possibilities, including the interplay of colours, dimensions, layout, and perspective, in a way that dissolves the ordinary screen limitations in other media (cinema and TV), and introduces its readers to the captivating interplay between the written text and visuals that allows expansion into different sign systems and meaning-bearing realms.

There are numerous possibilities in the medium of comics for conveying meaning: for example, metonymically using only one part of the body in the panel can be a powerful tool for focusing attention, especially when space constraints limit the author's possibilities of conveying a certain message in its visual totality. Of course, this is but one example of the characteristics of graphic novels as fertile ground for meaning conveyance. The multimodal ${ }^{2}$ nature of the comic book form

\footnotetext{
${ }^{1}$ As noted by Saraceni (2003: 4), the terms are interchangeable, since "graphic novels" was introduced in the 1970s in an effort to replace "comic" and point to a more versatile, genre-prolific endeavour in the comic book realm, although it never really took flight and remained in use only as a synonym.

${ }^{2}$ Multimodality refers to the presence of more than one mode or way in which figurative mechanisms are expressed, and in the case of comics, the modes incorporate text and image, which can
} 


\section{JEZIKOSLOVLJE \\ 20.2 (2019): 255-278}

enables the presence of conceptual metaphors and metonymies and is a key feature of this medium (Potsch \& Williams 2012: 18-19).

Since the medium of comics is predominantly sight-based, its creators have the entire world of visual iconography at their disposal, including the full spectrum of pictorial styles - from realistic representations, to simple cartoons, all the way to absolute abstractions, the world of symbols and a variety of languages depicted creatively - which instills power in the medium to command the reader's involvement and identification (McCloud 1993: 201-203). These styles are usually not mixed in other media, but the non-traditional take on visual elements is often employed and welcomed in graphic novels (especially in Dylan Dog), which gives these artworks another unique trait in the artistic dimension.

These combined verbo-visual posibilities, offered almost exclusively in the medium of comics, also enable the portrayal of Death in its most ubiquitous form, and in such a manner that invites linguistic research of the cognitive predicate. Dylan Dog, whose thematic characteristics go well with topics on dying, appears to be a suitable representative and research subject for this type of analysis, as its pictorial communication is often seamessly woven into a larger cultural narrative on the meaning of existence.

\section{Dylan Dog}

The comic book series Dylan Dog, created by Tiziano Sclavi in 1986, is one of the staples of Sergio Bonelli Editore, a major Italian comic book publishing house. The eponymous character is a self-proclaimed "investigator of nightmares," a private detective whose cases consist mostly of supernatural occurrences, and is accompanied by a barrage of other supporting characters, most notably his sidekick Groucho Marx, who shares an uncanny resemblance to the well-known comedy actor from the golden era of Hollywood. As is the case with comic books and their subsequent treatment in the realm of cinematography, Dylan Dog received two celluloid adaptations: The Cemetery Man or Dellamorte Dellamore in 1994, and Dylan Dog: Dead of Night in 2011, both with varying degrees of success in the translation of the visual and thematic characteristics of the comic to the big screen.

In dealing with various clients and intriguing cases, Dylan Dog frequently encounters Death in several guises. The two conduct conversations about the nature

point to the location of domains in combined modalities (for more on multimodality, see Forceville, Urios-Aparisi 2009). 
of life and human fate, and sometimes Death takes away Dylan's current love interest (in almost each episode he meets a new woman and falls in love, with mostly tragic consequences). The visual feel of Death, itself a personification of man's ultimate fear of dying and the unknown, is highly evocative of the canonical representation of death as "The Grim Reaper," a skeleton-like creature dressed in a monk's robe and holding a scythe, although the issues presented in the analysis contain several variations of this form.

The scope of the influence of Dylan Dog in the three decades since its inception in 1986 cannot be underestimated: not only is it one of the most-selling creations of its publishing house (Castaldi 2010: 134), but it frequently offers references to significant literary giants of the past, depicts important cultural issues of the present, and points to often negatively perceived strivings of the world at large (e.g. mankind's unhealthy relationship with technology). The fantastic elements for which the comic is known are often used as a backdrop for a more serious conversations - as it is stated in the depiction on the official web presence of Sergio Bonelli Editore: "But often the fantasy stories constitute a pretext for focusing more closely on the protagonist, to address burning social issues of the day, many of them unfortunately very real such as the presence of an underclass, vivisection, drugs, racism, violence and the tyrannical power of the mighty." 3 Dylan Dog also served as a bridge between the fumetti neri (black comics) of the 1970s and the early ' 80 s in Italy and the present day, as noted by Castaldi (2010: 134-135), who points to its inception as a pulp horror publication aimed at young adults, the narratives of which "were imbedded with intertextual references (pulp and B-movies specifically), and it configured itself as a sort of soft late-post-modern meta-narrative." cult status of this comic was cemented by Umberto Eco, who said: "I can read the Bible, Homer and Dylan Dog for days and days...," with Sclavi often paying homage to the famous Italian writer and semiotician with citations and a character depicting Eco in one of the more recent issues. ${ }^{5}$

\section{The Grim Reaper blend}

The Conceptual Integration or Blending Theory by Fauconnier and Turner (1998) is based on the concept of mental spaces, which can be defined as conceptual

\footnotetext{
${ }^{3}$ http://en.sergiobonelli.it/section/2569/dyd-s-world (last accessed: September 27, 2019).

${ }^{4}$ Wilkins (2015: 226-227) uses an episode of Dylan Dog thematically connected to Melville's Moby Dick to discuss its intertextuality and reinterpretation of meaning in the source reference.

${ }^{5} \mathrm{http}$ ://en.sergiobonelli.it/section/2569/dyd-s-world (last accessed: September 27, 2019).
} 
'packets of knowledge' constructed during the process of ongoing meaning construction, and structured by idealized cognitive models (Evans \& Green 2006: 279). The process of conceptual integration or blending is a basic mental operation that allows us to blend two or more already present mental spaces into a third one, a novel mental space which is not simply a composition or a simple "sum of its parts", but possesses an emergent structure of its own (Fauconnier \& Turner 1999: 77).

As opposed to Conceptual Metaphor Theory, in which the structuring of human understanding in the form of conceptual metaphor is presented with a two-domain model, the process of conceptual integration consists of several input spaces, those being: input space 1 and 2, which are recognized as similar to the concepts of source and target domains in conceptual metaphor, with the exception that more than two input spaces can be employed in some blending operations; ${ }^{6}$ the generic space, consisting of elements shared by the two input spaces and represents their indirect connection; and the blend, crucial for the interpretation of a construct since it contains an entirely new scenario, comprised of known elements from the two (or more) input spaces. Blending as a cognitive operation leads to creative constructs in language and other areas of cognitive production (thus encompassing many products of human creativity), and due to its tight structure and constraint, human beings are able to recognize, manipulate and produce such operations (Fauconnier 1997, 186). ${ }^{7}$

In their Conceptual Blending Theory, Fauconnier and Turner (1998) have unearthed the specific representation of Death as an example of how a complex integration deals with several mental spaces. The Grim Reaper, traditionally depicted as a sinister, skeleton-like character holding a scythe and wearing a cowl, is an integration involving complex interactions of metaphor and metonymy. Fauconnier and Turner (1999: 83-84) envisioned the blend for Death as an amalgam of four main input spaces, which relate to four agents: 1) DEATH, which carries out the death of a person 2) a REAPER, who uses a scythe to cut down plants; 3) a (human) KILLER $^{8}$, who murders a victim; and 4) CAUSAL TAUTOLOGY, where an event of a

\footnotetext{
${ }^{6}$ This proves to be an especially attractive element of BT/CIT for creative blending.

${ }^{7}$ We must note that Veale et al. (2009: 48) argue that BT/CIT can only model creativity in hindsight, since, according to the authors, creativity lies in the choices made in populating the input spaces, and not in the processes of projection and integration. However, we also recognize the issue of generalizing creativity as "finding pertinent patterns in pattern breaking," and usefulness of the theory in researching certain aspects of comic books (Forceville 2009: 253).

${ }^{8} \mathrm{We}$ are aware of the somewhat problematic use of the term „killer“, as it connotes a violent death, while the Grim Reaper, in general, can be seen as a force harvesting a human life at the end of its
} 
certain kind is caused by an abstract causal element: e.g. Death causes dying, Sleep causes sleeping, and so on. In conceptual terms, however, The Grim Reaper resides in none of these input spaces, but in a blend with projected structure from all of these spaces. The unique nature of this blend is shown in the connected input space of CAUSAL TAUTOLOGY: the authors (2002: 291) note that, although there are many ways of dying, all have a single, overarching cause, Death, for which there is no referent and no evidence other than the effects themselves. This makes the Cause defined in terms of the event category, and is simultaneously referred to by these very terms. Along with the input space of HUMAN DEATH, containing manner and specific event of dying, these input spaces structure an elaborate blend of DEATH as a killer who performs the act of killing with the result that the person/victim dies. However, the blend is not finished when looking at these spaces alone: the input space of the REAPER projects not only the visual element consistent with the image of the Grim Reaper, which is the scythe traditionally used for reaping, but also yielding any sort of mortal authority over its actions.

The causal link in the representation of death as the Grim Reaper is confirmed by Lakoff and Turner (1989). In their analysis of the metaphorical conceptions of death, the authors approach the Grim Reaper image from the point of view of CMT, where the metaphoric personification of DEATH IS A REAPER comes from a twofold composition of the metaphors EVENTS ARE ACTIONS and PEOPLE ARE PLANTS, as people who are dying are perceived as plants which are harvested by the reaper (Lakoff \& Turner 1989: 79). Because we can view the Conceptual Metaphor Theory, which is used for 'traditional' conceptual analysis of conventionalized and well-known metaphorical expressions, and the Conceptual Integration Theory, which is suitable for the analysis of innovative metaphors and their real-time modelling, as the end points of the same continuum-where the meaning can be learned, systematized and stabilized through continuous use (Matovac \& Tanacković-Faletar 2009: 134-139; Stanojević 2009: 362-363), we can note how the blend for The Grim Reaper can be constructed with the help of these metaphors in its creation and establishment in the cultural consciousness. It is important to also note the metonymic connections in the Grim Reaper inputs. Evans and Green (2006: 432) recognized the physical appearance of the Grim Reaper as a metonymical representation of each of the three main inputs (excluding CAUSAL TAUTOLOGY): the skeleton which stands for DEATH as the outcome, the hood which hides the reaper's

natural cycle (as harvest is reaped at the end of its maturation). However, in light of the depictions of Death in the corpus, we felt that it is consistent with the conducted research (for more on this disctintion, see Belaj 2005). 
face as the concealment that often characterizes KILLERS, and the scythe representing the manner of killing, derived from the REAPER input. Moreover, the hooded creature of the reaper is most often depicted as a skeleton, but in the cross-space mapping, there is no counterpart connection between skeleton and reaper, skeleton and killer or skeleton and death. But the blend allows these non-counterparts to be combined by exploiting the metonymic connections of death as a cause and skeleton as an effect, which enables this combination in the blend. In a similar manner, the input space of human dying is metonymically connected to priests as representatives of an institution concerned with death and afterlife, taking into account the fact that priests are stereotypically present at the deathbed of a person. Therefore, even though reapers and priests are not counterparts, the attire of a priest is metonymically projected onto The Grim Reaper, and the cowl, pulled over the head of this representation of Death, evokes both religious connotations and the impression of death as mysterious, solitary, and set apart from ordinary events in human society (Fauconnier \& Turner 2002: 84). This projection is an important element of the classic depiction of Death, especially in medieval iconography, and it is present in numerous works of art from that period. In this sense, the interconnectedness of signs, and their identities, point to the mutual relation of metaphors and metonymies where the core of their correlation lies in the formation of artworks as sign systems (Somov 2013: 31), in which the Grim Reaper as a character is often portrayed in specific figurative terms.

\section{Methodology}

The corpus was chosen from a collection of 300 editions of Dylan Dog, published in Croatia from 1994 to 2018 - first by Slobodna Dalmacija publishing house, and afterwards by Ludens and Libellus. Within these editions, we limited the search to regular monthly instalments, while special issues such as Dylan Dog Gigant, Dylan Dog Maxi and Almanach of Fear (Almanah straha) were excluded. ${ }^{9}$

The four comic book episodes discussed here are thematically chosen for their prominent representation of the stereotypical Grim Reaper or variations of it - as is the case in A Chess Game with Death (1994), On the Other Side of the Mirror and Danse Macabre, or present a non-traditional depiction of Death, as featured in the issue titled Paper Dungeon (1998). By delving into four specific episodes/ instances of the representation of Death in Dylan Dog, we will attempt to determine the

\footnotetext{
${ }^{9}$ Partly because some of the stories are republished in special editions, such as Danse Macabre or Totentanz in Dylan Dog Gigant No. 5.
} 


\section{Ilhana Škrgić:}

Figurative representation of death in the Italian comic book Dylan Dog

classic and modern elements of visual depictions of the Grim Reaper, following the blend structure discussed in Fauconnier and Turner (1998; 1999). In addition, this research will try to point to the issue of medium-specificity, in terms of unique possibilities of depicting the Grim Reaper in graphic novels.

Our analysis deals with the selected comics on three levels: the descriptive level, used to introduce the story of the episode and the manner of character representation; the visual level, where the focus lies in the manner of visual/multimodal depictions of Death; and the blend level, in which the depiction is analyzed through the visualization and explanation of the blend. In the selected episodes, all panels that feature the representation of Death were analyzed, focusing on the points of correspondence between Fauconnier and Turner's blend for The Grim Reaper, and its visual characterization in the analyzed issues, with emphasis on the specific points of realization unique to the medium of comics. Additionally, several panels of the comics are added to the analysis to provide evidential support.

\section{Analysis}

\subsection{A Chess Game with Death}

Conceived by Claudio Chiaverotti, the episode $A$ Chess Game with Death (Partita con la Morte) is inspired by The Seventh Seal (1957), a film by Ingmar Bergman in which a medieval knight plays a game of chess with the Grim Reaper. In Dylan Dog, every time Death "eats" one of the chess figures, the opponent must choose the person from his immediate surroundings who will die in order to postpone his own passing, or perhaps stay alive by attempting to win the game.

The symbolism of Death in this episode is unmistakable: like the other iconographic elements of the series, such as the unfinished galleon maquette, the clarinet that Dylan uses to render a screeching version of Tartini's Devil's Trill, ${ }^{10}$ or his mannerisms in dressing and movement, the image of the Grim Reaper is part of the surrealist milieu of Dylan Dog, a natural element in his detective search, and the threshold in his quest to understand the unknown. In this instalment, Death is also the crucial character whose actions reverberate through the thin veil between life and death and influence Dylan's investigation of bizarre deaths (i.e. the persons connected to the chess player and marked as "fallen figures" in the game).

\footnotetext{
${ }^{10}$ Readers, of course, cannot hear the rendition of the sonata; however, the quality (or lack thereof) is pointed at by verbal communication between Dylan Dog and other characters (written in speech balloons), and by visual signs or "pictorial runes," such as distorted music notes (for more on pictorial runes, see Forceville 2003).
} 


\section{EZIKOSLOVLJE}

20.2 (2019): 255-278

The look of Death is entrenched in popular culture and accurately transferred into this episode by way of physical appearance, size and colour. As such, the Grim Reaper is perfectly in tune with the possibilities of conveyance in comics, since the authors require only the standard means of creative production to portray this character and its interaction with others in the episode (see Figure 1).

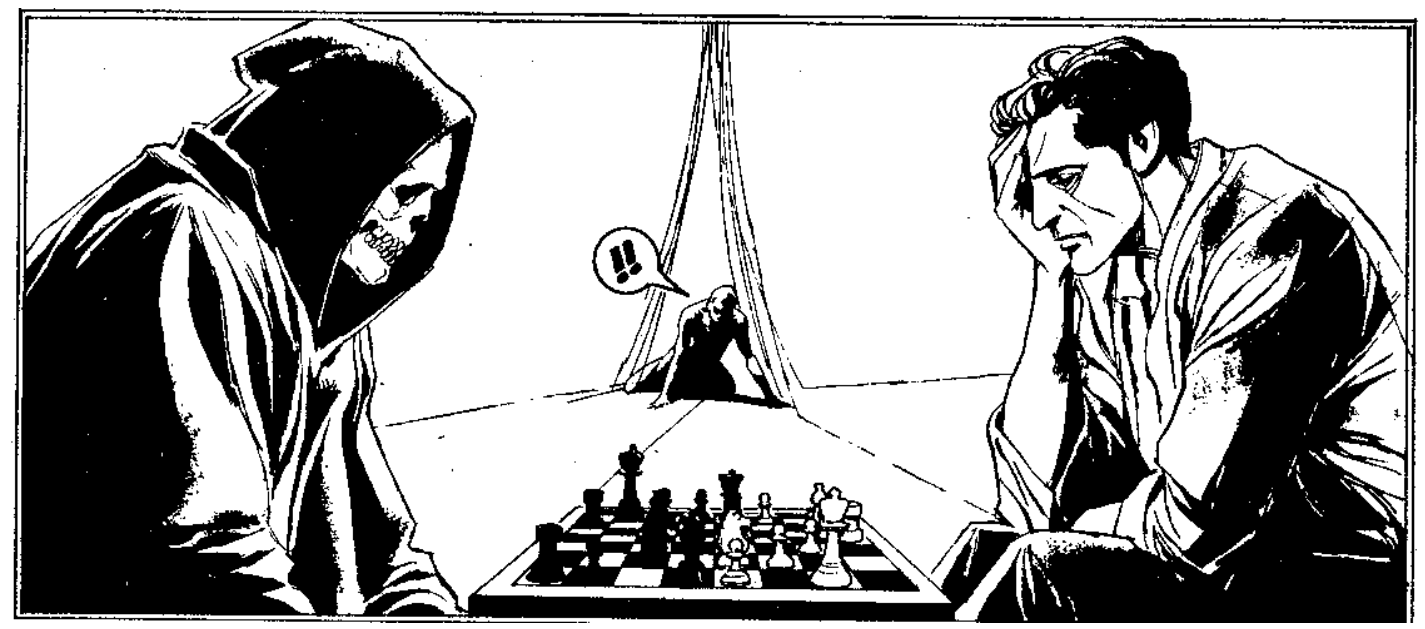

Figure 1. A Chess Game with Death, top panel on page 26. (C) Sergio Bonelli Editore.

The visual style of the comic, in the hands of illustrator Corrado Roi, reflects the main topic in its sense of supernatural dread: since Dylan Dog is mainly published in black and white, the monochromatic treatment is enhanced by the shadow play and often reversed main colors (meaning, objects that in real life are black/dark are depicted as white/light and vice versa). The various drawing artists of Dylan Dog, most notably Roi, Casertano and Piccatto, use the page layout and a clever manipulation of the reader's perspective to accentuate Death's position over mortal man. In one of the panels of the episode (see Figure 2), the Grim Reaper is towering over the reader, who appears to be looking at it from a position of a person lying down (seen by the length of the robe). Intentional positioning of the reader (participant viewpoint) creates a moment in which the reader is "drawn into action," which is used for dramatic effect (Potsch \& Williams 2012: 24). 


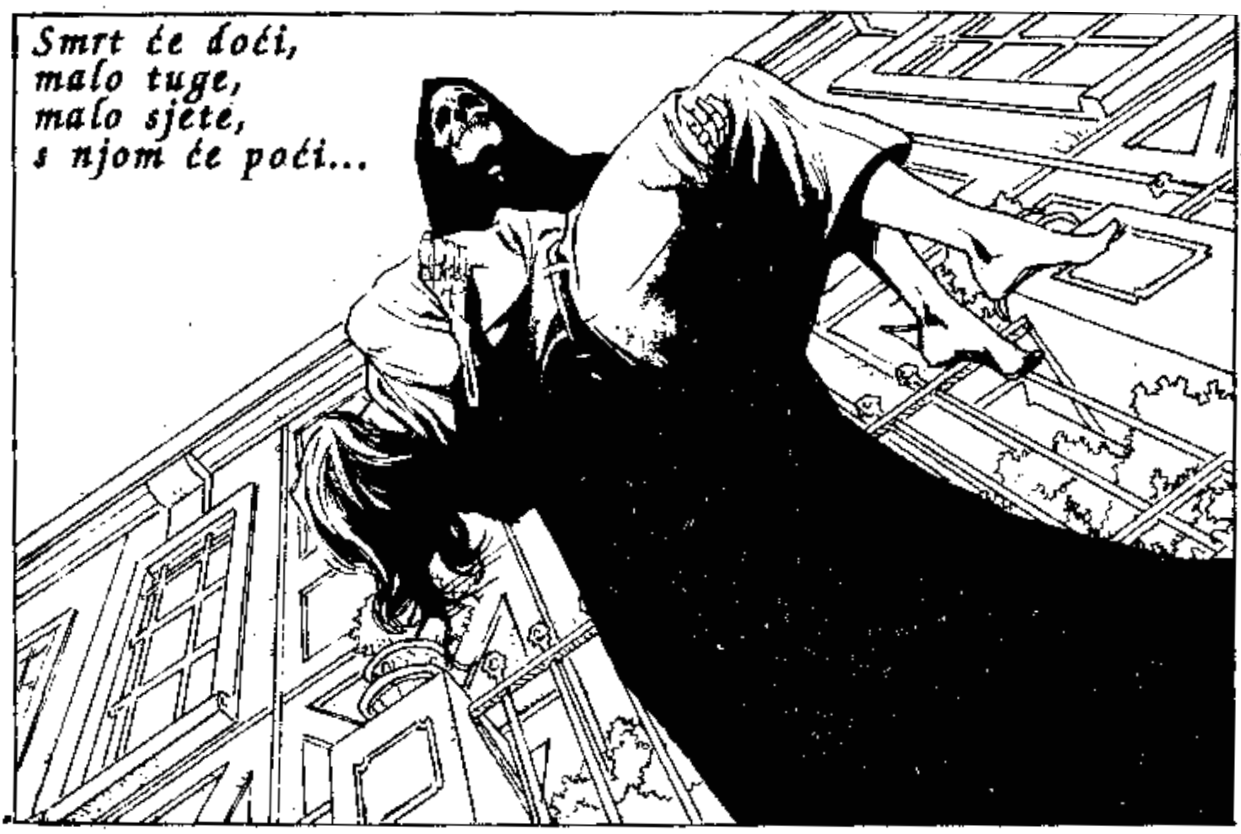

Figure 2. The perspective in A Chess Game with Death, end panel on page 61. (C) Sergio Bonelli Editore.

In another panel (see Figure 3), Roi uses the contrast in the panel with the white sky, sort of an inverted achromatic image of a night view, where the black area actually indicates the beginning of the Grim Reaper's robe. This is in line with McCloud (1993: 192), who noted that the ideas behind the art of comics are communicated more directly in black and white, in a way that makes meaning transcend the comic book form. In a visual sense, the reader thus sees Death as a "larger than life," all-encompassing character that transcends the limitations of space and time (represented by the sky and time of day). 


\section{EZIKOSLOVLJE}

20.2 (2019): 255-278

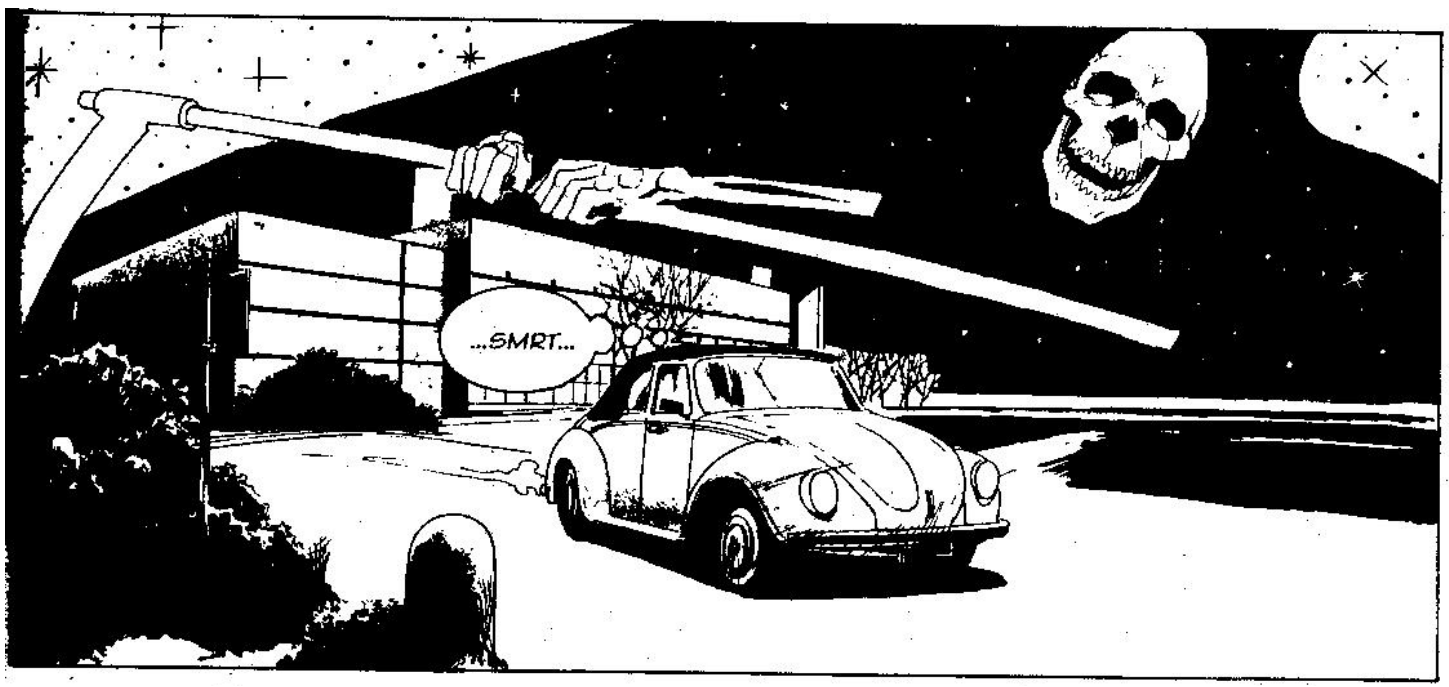

Figure 3. The Grim Reaper in A Chess Game With Death, end panel on page 41. (C) Sergio Bonelli Editore.

The blend for The Grim Reaper (Fauconnier \& Turner 2002: 292) is respected in its entirety with the visual design for the issue (Figures 1, 2 and 3). The blend, consisting of the input spaces of DEATH, KILLER, REAPER and CAUSAL TAUTOLOGY, possesses the traditional elements visually connected to Death: the long monk's robe, a scythe, which Death holds during the chess game, the skeleton underneath the robe, and performing the killing of people which is presented as consequences of Death taking over the figures of his opponent on the chessboard. Therefore, another layer of figurative representation is added to the blend: The Grim Reaper reaps the victims of the game by knocking down the figures that are metonymic representations (CHESS FIGURE FOR INDIVIDUAL) of the people being killed by DEATH-AS-AGENT.

This is representative of episodes where the main character and Death only have a secondary connection through other characters and their story arcs. However, as we will see from the later episodes, Death became "more aware" of Dylan Dog and found ways to incorporate this character into her grand plans, ${ }^{11}$ gaining in significance for the series in total.

${ }^{11}$ The use of the feminine pronoun for Death in this paper is in line with the Croatian translation of the analyzed issues and the feminine portrayal of the trope in several instalments. 
Ilhana Škrgić:

Figurative representation of death in the Italian comic book Dylan Dog

\subsection{On the Other Side of the Mirror/Danse Macabre}

In this section we combine the analysis of the episode On the Other Side of the Mirror and Danse Macabre, since The Grim Reaper in these instalments is portrayed in a similar manner.

Titled Attraverso lo specchio in its original printing in 1987, the episode On the Other Side of the Mirror, written by Dylan's creator Tiziano Sclavi and penciled by Giampiero Casertano, is a lament of sorts about Death and its inevitability, coupled with a poetic view on dying and a ballad about the Grim Reaper. This is an episode where Dylan and Death have one of their important meetings, and as with many issues in this comic book series, it was inspired by a short story-namely, The Masque of the Red Death by Edgar Allan Poe.
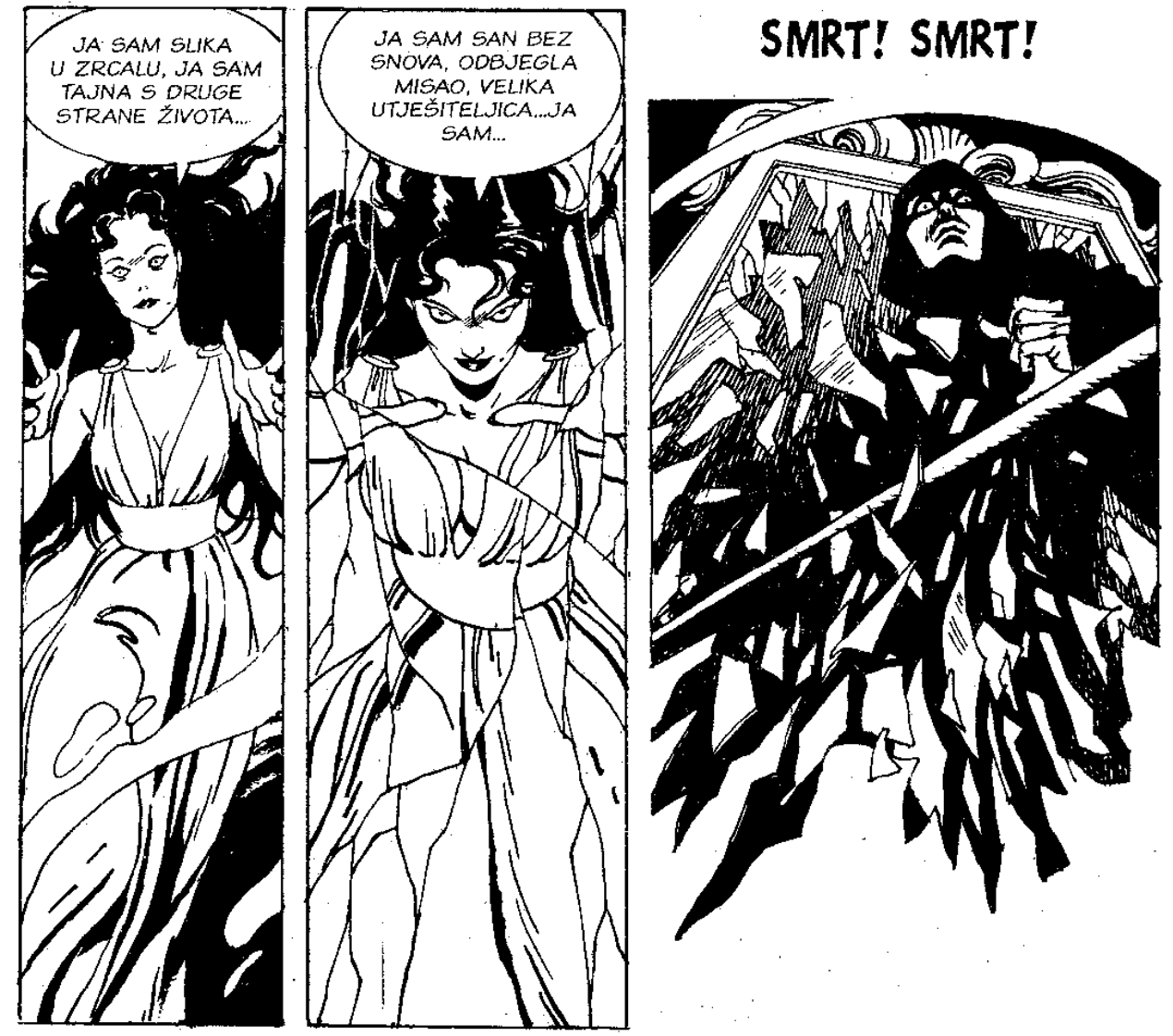

Figure 4. The Grim Reaper in On the Other Side of the Mirror, panel sequence on page 96. (C) Sergio Bonelli Editore. 


\section{EZIKOSLOVLIE}

20.2 (2019): 255-278
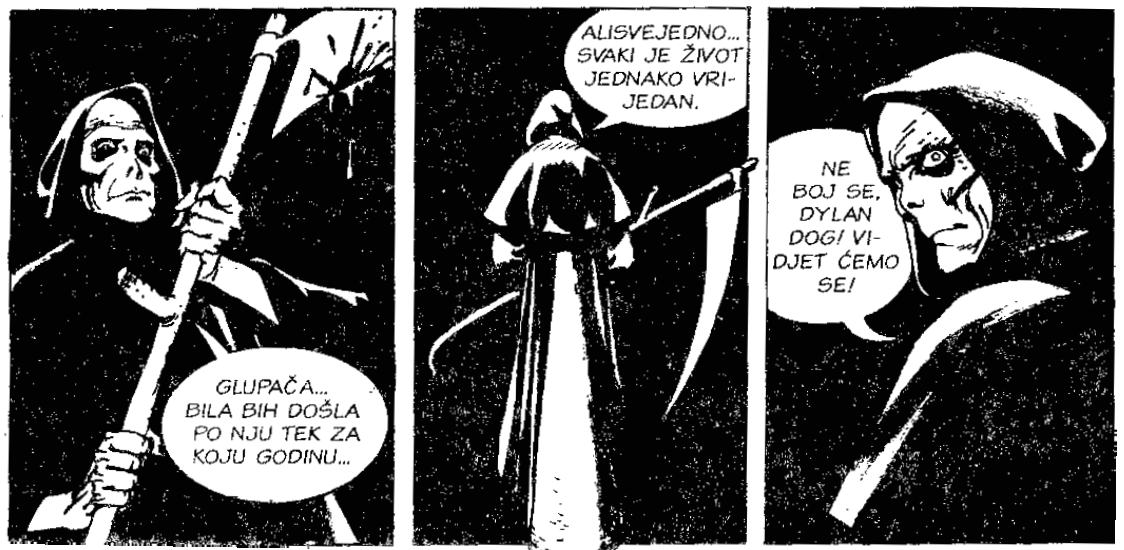

Figure 5. The Grim Reaper in On the Other Side of the Mirror, panel sequence on page 98. (C) Sergio Bonelli Editore.

Danse Macabre, a representative of episodes devoid of linear narration, shows Dylan meeting a mysterious woman in a cemetery named Hope who places flowers on the graves of unknown men, thus provoking their spirits to rise up and tell their story to Dylan as he graples with their tragic fate and absurd ways in which Death manifested in their lives. Unlike the next episode in the analysis, in which it appears in a side-story, in this issue Death is the line connecting the individual life stories presented to Dylan, an intermezzo of sorts, and the form which it takes throughout the episode varies from a beautiful lady with curly blonde hair to the fully-formed Grim Reaper (see Figure 6).
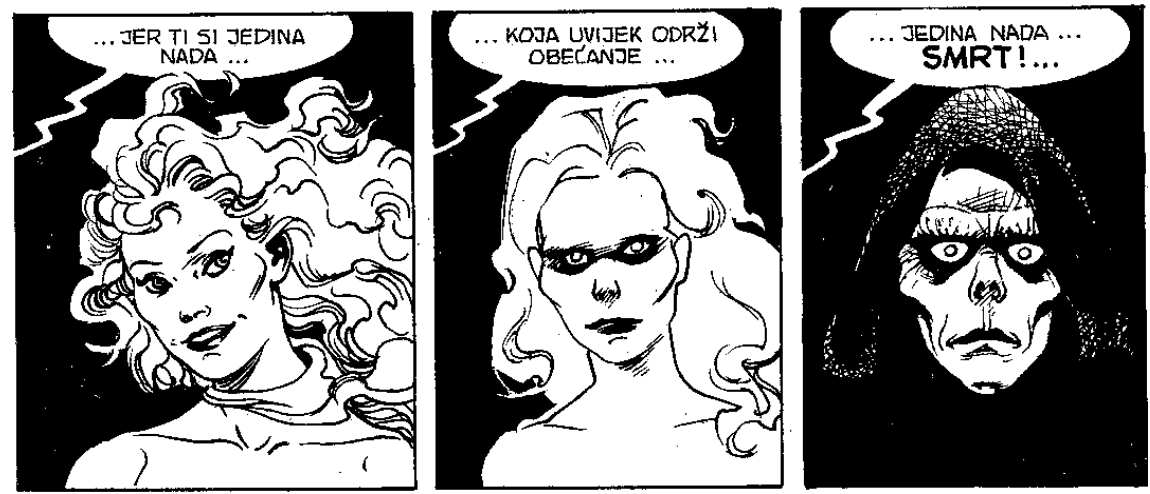

Figure 6. The Grim Reaper in Danse Macabre, panel sequence on page 68. (C) Sergio Bonelli Editore.

The look of Death in both episodes (Figures 4, 5 and 6) by and large follows the classical depictions with the robe and cowl, but gives an uncharacteristic twist to it: 
the face seems elongated, as if Death is starved, and the eye sockets are not empty or filled with darkness, but real and drawn in a way that suggests a questioning stare. The face and the hands are not skeletal, which makes the physical manifestation of Death closer to a living human being, thus erasing the counterpart of skeleton from the non-counterpart connections establishing the Grim Reaper blend. However, with the presence of the cowl and scythe, the blend does not lose its meaning as a reaper bringing about the death of affected persons. The blend is presented in the following diagram:

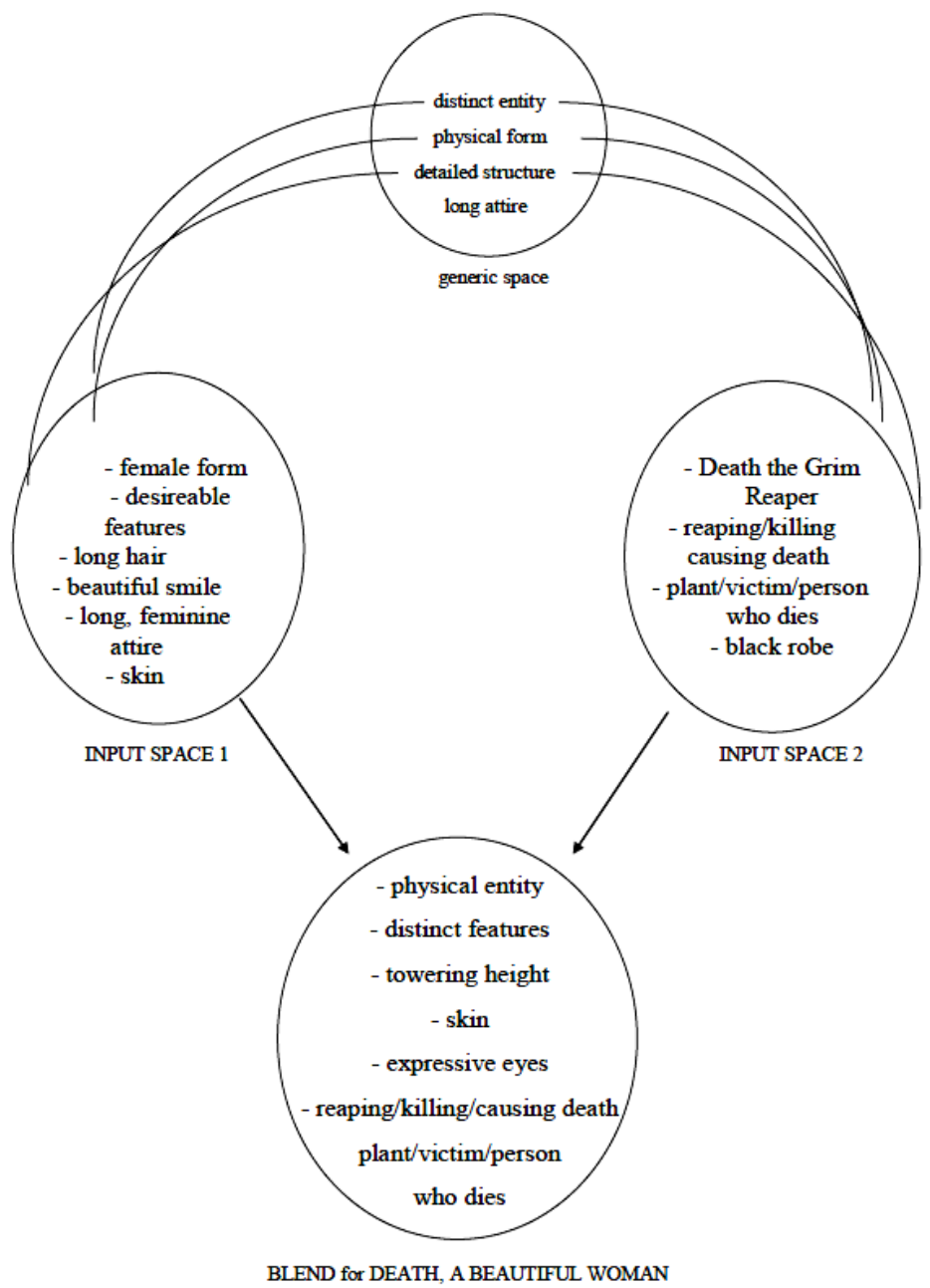

Diagram 1. Death, a Beautiful Woman network.

In input space 1 we have the features of a female or a feminine body, a living creature with attractive attributes and all elements pointing to a regular human be- 
ing, as opposed to input space 2, where the classic elements of the Grim Reaper visualization are present, including the scythe, the black robe, and the method of reaping. The generic space contains mutually shared characteristics, such as the distinct, physical form of the creature and its detailed structure. The emergent structure retains some of the essential characteristics of the two input spaces, but the most important attributes are created in the blend for Death that presents itself as a combination of a skeleton and a living being, e.g. the elongated face and thin hands, but with flesh. This has the effect of transforming the classic depiction into an unusual and more disturbing creature, since the novel elements change the interpretation of the blend construct.

Sclavi imbued the Danse Macabre with a poem on the Grim Reaper which is intervowen throughout the issue, and, along with another poetic edition in the form of Ballade of the Hanged Men by the French poet Francois Villon, the episode achieves an ode-like status to Death. The metaphoric language is used to add an additional, poetic dimension to Death, since the poem is written from the point of view of people affected/taken by Death, which in turn adds a multimodal aspect to the Grim Reaper visualization. Let us consider the following verses:

If we have called you brothers, you should have patience: the rope of justice

will befall you, but you are aware, that for her, not all men are the same. ${ }^{12}$

The text of the poem is written on a one-page panel with a drawing of corpses hanging from an enormous tree, presented after several panels of Hope's transformation to Death. Compared to the original version of the poem by Francois Villon (translated by Richard Wilbur), ${ }^{13}$ the verses introduce a key difference: whereas Villon emphasizes the religious aspects of the plea of the hanged men, Sclavi's verses refer to Death as "her" and present it as the ultimate giver of "justice," in which God and the Virgin Mary are somewhat juxtaposed to the merciless Grim Reaper. The change can be interpreted as the author's attempt to further emphasize the metamorphosis of the classic portrayal of the Grim Reaper to a creature that retains most of the figurative qualities of the blend, but with an added human dimension. Moreover, by using the gender-specific pronoun for Death in order to define it

\footnotetext{
12 Translation by I.Š. of the poem version that appears in the episode Danse Macabre (the version is noted as a "free interpretation" by Tiziano Sclavi, and subsequently translated into Croatian for the edition by Slobodna Dalmacija).

$13 \mathrm{https}$ //hudsonreview.com/2013/02/villons-epitaph-ballade-of-the-hanged-men/ (last accessed on September 27, 2019).
} 
as a female entity, and by enhancing the effect in visual terms, Sclavi accentuates the horrific effect of the joining of two opposing forces: life and death, personified by a beautiful woman on one side, as a sign of nature, birth, and romantic love, and the canonical portrayal of Death on the other, as the end of life and entrance into the unknown.

\subsection{Paper Dungeon}

Originally published in 1996, La prigione di carta or Paper Dungeon represents a Dylanesque homage to one of the most controversial and unique American pens, Charles Bukowski. When a series of murders happens in London, Dylan is called into service by a group of homeless people who want to free their friend, now a murder suspect. Not only do the murders have a grotesque nature, but they are committed by characters seemingly ripped out from the pages of stories by Charlie Chivazky, an American writer who went missing in London after arriving to promote his latest work. The writer discovered the ability to trap his demons on a piece of paper with the power of his writing: as soon as he writes a story about a particular demon that has been torturing him, the demon disappears. After his untimely death, the demons roam free through the streets of London with morbid consequences. Michele Medda wrote the story, while the visuals were managed by Luigi Piccatto, whose distinct style was well-chosen for the story type (grotesque and black-humored, rather than the unsettling, horrific type typical of Roi, for example).

As a story within a story, the panels follow an encounter between a man and a slightly unattractive woman, whom the man refers to as "stingray" in his internal monologue. One of those characters is "The Girl That No One Wants To Kiss/Stingray," a particularly captivating portrayal of Death as a full-figured middle-aged woman with thick glasses who goes on a double date together with her more attractive blonde friend. When the date still goes the desired route (i.e. despite the man being initially turned off by the woman's physical appearance), the man is shocked to discover her true nature behind the glasses - a Lovecraftian monster forming out of the female features, with accentuated black skin and an elongated form. Brimming with black humor, the episode also presents the monsters as entities fully aware of their killing nature, offering short explanations, such as when Chivazky's Death explains her choice of representation to the unfortunate man. He insists on the woman taking off her glasses, which in turn catalyzes her physical transformation (see Figures 7 and 8). 


\section{EZIKOSLOVLIE}
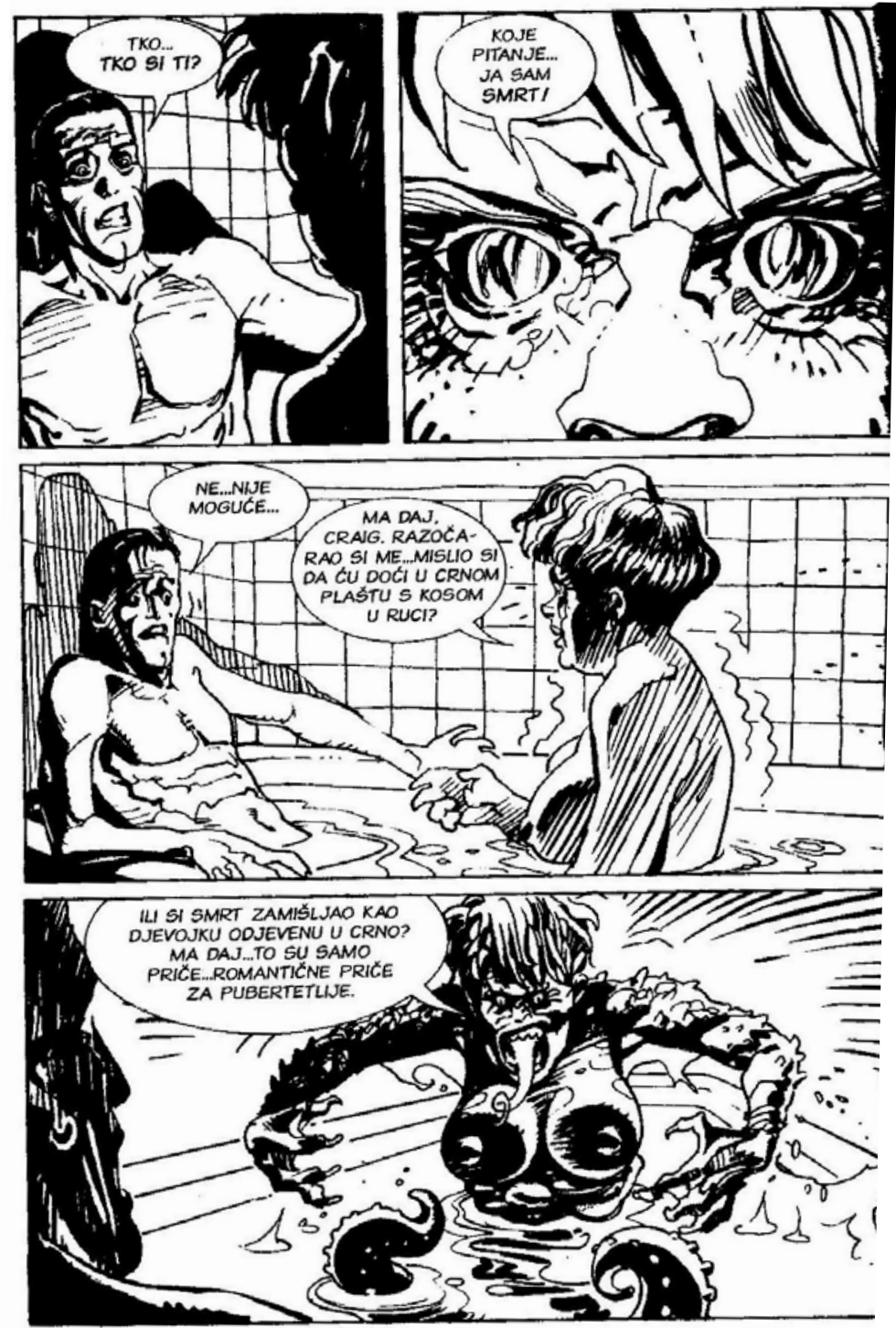

Figure 7. Death in Paper Dungeon, panel sequence on page 42. (C) Sergio Bonelli Editore. 
Ilhana Škrgić:

Figurative representation of death in the Italian comic book Dylan Dog

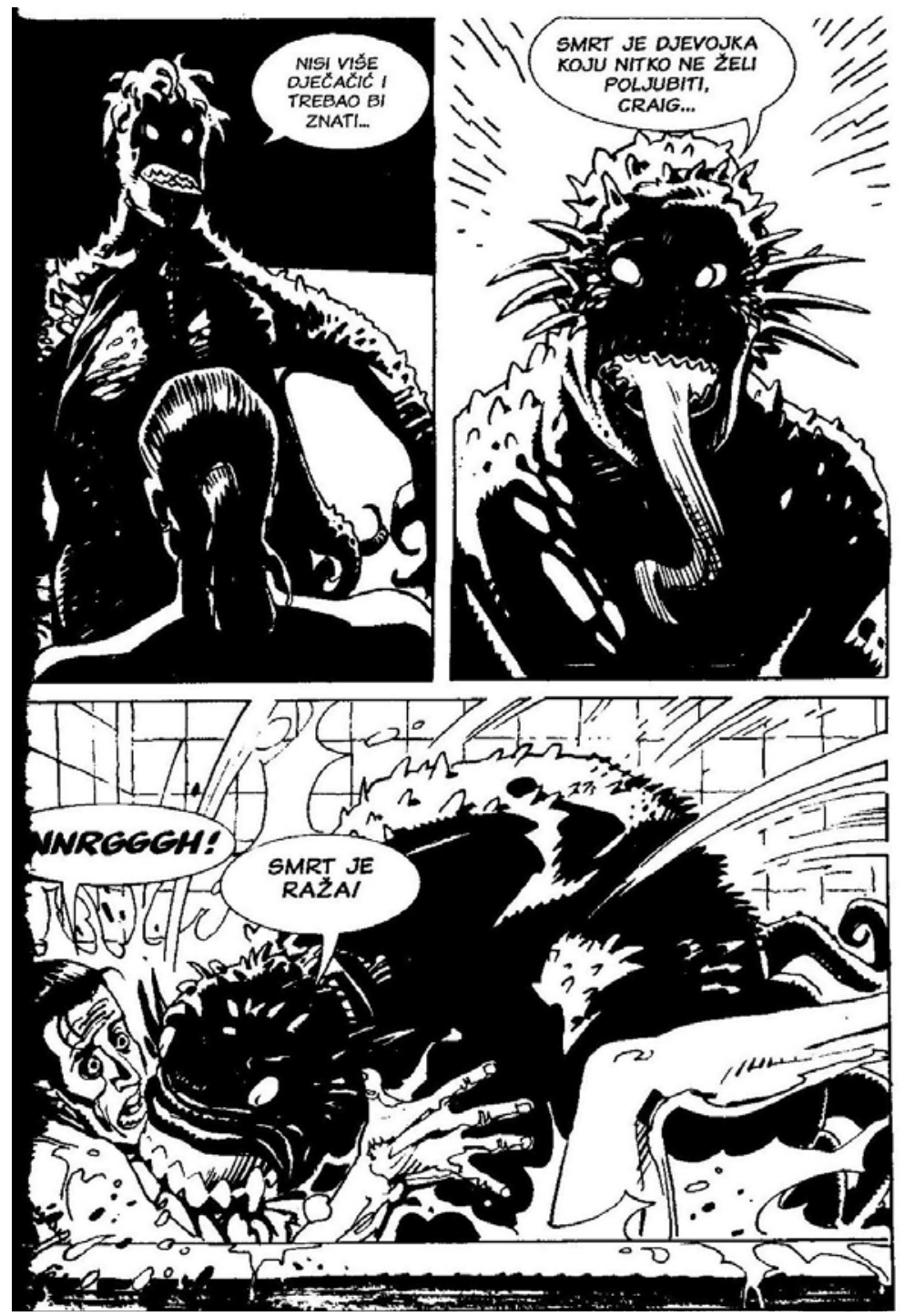

Figure 8. Death in Paper Dungeon, panel sequence on page 43. (C) Sergio Bonelli Editore.

As the creature rises unnaturally above the male character, it exclaims "Death is a girl that no one wants to kiss... Death is a stingray," while the visual form of the woman/monster becomes an amalgam of human, death and stingray features. The element of color is also important: the final, emergent structure is black, which points to the input space of Death, and in particular, the black monk's robe. 
The blend for "The Girl that No One Wants to Kiss/ Stingray" is presented as follows:

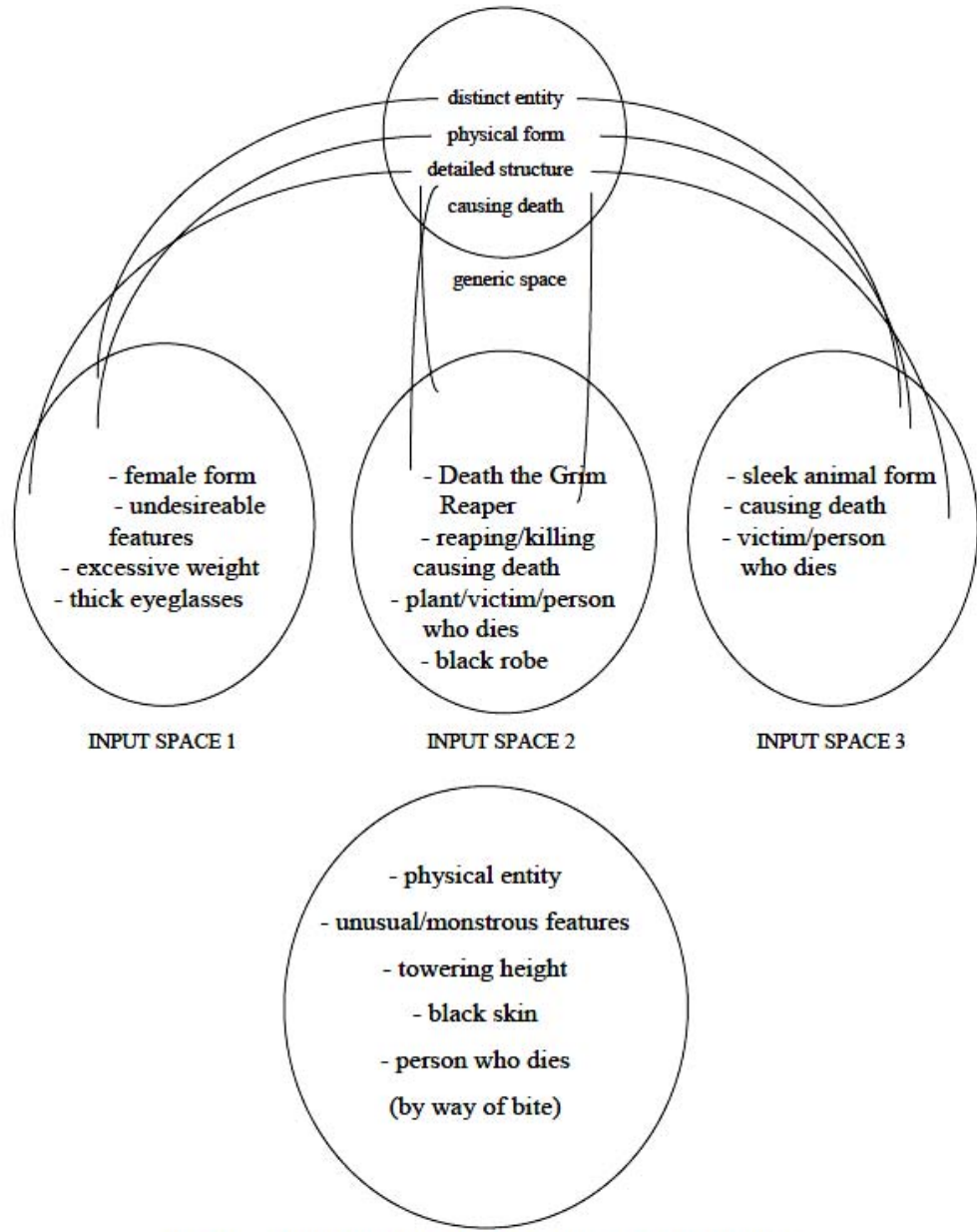

BLEND for THE GIRL THAT NO ONE WANTS TO KISS/STINGRAY

Diagram 2. The Girl That No One Wants To Kiss/ Stingray network.

The blend (Diagram 2) was created using three different input spaces: in input space 1 , we have the female form, but with rather unattractive features, which is an intentionally humoristic take on the previously presented feminine body (in the dialogue of the two characters, the creature asks the man if he thought she-Deathwill come as a beautiful girl dressed in black); input space 2 contains characteristics of the traditional representation of Death, while input space 3 possesses charac- 
teristics of a slightly dangerous sea animal which can, in certain, though rare cases, cause death. The emergent structure retains some of the attributes of each of the input spaces, such as color and weight, but the new, compound entity contains novel characteristics, mainly reflected in its unnatural form and height, black skin (color transfer from the monk's robe), tentacles instead of human extremities, and the manner of inflicting pain/causing death (by biting the male character). The monstrous nature of Death is thus visually presented in the blend in a non-traditional manner, where the authors transformed the classic depiction of the Grim Reaper into a creature with no clear visual reference to it. The blend is further enhanced by manipulations with the panel dimensions: before the revealing of the monster, the panels are sequenced and possessing proportions corresponding to the characters; however, once Death has shown its true form (see Figure 8), the panels are enlarged in an effort to complement and accentuate its dimensions.

Furthermore, in the panels that precede the final revelation of Death, where the character demands to see the woman in complete nudity and without her glasses, the authors have employed the classic conceptual metaphor UNDERSTANDING IS SEEING, since this demand alone triggers the shift and it is unclear whether the Grim Reaper would have appeared at all if the demand was not voiced out explicitly. Not only is the character then introduced to its monstrous form, but the removal of the glasses represents the "shedding" of the human appearance and thus forms a metonymic connection that enables the vizualization of the emergent structure, i.e. the blend in Diagram 2.

As with the previously analyzed issues, the feminine body is again employed to induce shock in the readers: the aesthetically pleasing appearance (inherent to Western beauty standards) was replaced with an unassuming, motherly form, which strengthens the horrific juxtaposition to the dangerous, monstrous entity in the final panels. In addition, this depiction adds to the mounting horror because it strips away the more palatable way of personifying Death, which the readers became accostumed to in previous instalments. Here, the Grim Reaper is not a beautiful woman, but an ugly, almost otherworldly creature that inhabits a different dimension, and offers suffering instead of peaceful absolution. Such a depiction, therefore, justifies the accumulated fear. Charlie Chivazky can be viewed as Medda's attempt at an avatar for himself (the writer), and to an extent the reader as well. The readers want their fear to be justified, not pampered and beautified by the illusion of a beautiful human awaiting us with a gentle hand and ushering us into a new place. Au contraire: Death is cold, dark, ugly, and provides only pain. In this sense, this instalment is a satire of the Grim Reaper depictions in previous episodes, emphasized by the character's own words (in Figures 7 and 8), where the 


\section{JEZIKOSLOVLJE \\ 20.2 (2019): 255-278}

rising Death rhetorically asks the man if he expected a cowl and a scythe, or a beautiful woman dressed in black, deeming both versions as romantic stories for teenagers. The self-awareness of the issue amplifies the overall story arc of Dylan Dog and Death into a circular interaction between characters on the opposite sides of the existential spectrum.

\section{Concluding remarks}

This paper presents an attempt at deciphering the visual representation of Death as the Grim Reaper in the Italian comic book Dylan Dog, from the viewpoint of Conceptual Integration Theory, which views the canonical depiction of a skeleton-like figure wearing a hood and cowl and holding a scythe as a blend of several input spaces, such as DEATH and REAPER. The traditional depiction of the Grim Reaper is a highly recognizable figurative construct that evokes a sense of unease and dread in the spectators of products of human creativity, most notably in the visual realm.

Fauconnier and Turner (1998) present the Grim Reaper as a complex integration of several mental spaces, where the combination of DEATH, as an agent performing death of a person, KILLER, who ends a victim's life, REAPER, who reaps plants with a scythe, and CAUSAL TAUTOLOGY, where events are caused by an abstract element, form a blend structure of a skeleton in a monk's robe, with a scythe and overall grim appearance. In the visual dimension of the comic book series Dylan Dog, the artists creatively vary on this classical trope: the Grim Reaper has both the traditional form, presented in the episode A Chess Game with Death, and modern and creative variants of this form, in the episodes On the Other Side of the Mirror, Danse Macabre and Paper Dungeon, where the latter presents a culmination of the transforming identity of Death with three input spaces forming a novel compound of monstrous appearance and proportions, and employing several metaphoric and metonymic connections to strengthen the blends.

By connecting the image of dread to a feminine body, the authors intentionally play with the classic perception of death, leading the readers in various directions: from a serene, accepting visualization to a horrifying, absurd final appearance. The novel representations of the Grim Reaper were deliberately placed in a female form to enable the perfect juxtaposition of Eros and Thanatos and their eternal interplay in human lives, often devoid of all meaning. Since Death could be hidden in a feminine body, which is able to give life, and in some instances being served as punishment for primal urges, the characters in Dylan Dog (therefore, the readers as well) are faced with questions about the significance of their existence, fear of dy- 
ing, and perishment.

Panel layout and the monochromatic design of the comic are used as enhancing elements in the overall meaning construction, and in the analyzed issues, the images were enriched with textual references in the form of dialogues and poems, thus forming a larger, dramatically portrayed narrative on Death and the meaning of existence.

The placement of the Grim Reaper as one of the characters in the series enables a symbiosis of the realistic and the fantastic, the flight of mind into the world of what ifs, thus materializing the fear from the abstract and the intangible into the dimension of the concrete, a construct that helps organize the readers' primary response to it. The medium of comics offers a type of "freedom of the linguistic code" shared between the authors and the readers - traditional constraints of other arts are minimized or made obsolete by the hybrid capacity of graphic novels, where the written and visual content is mutually complementary, and often creatively produced.

Taking into account the potential of researching the conceptual composition in question from a multimodal perspective and using various gender aspects, this paper can be viewed as a stepping stone to this type of analysis. Another interesting perspective would be a comparison of Dylan Dog and other thematically connected comic book series released in Western countries with the famous manga comics in Japan, in order to discover the difference in cultural portrayals of Death, and how Conceptual Blending Theory/Conceptual Integration Theory can shed light on these depictions and their core medium-specific differences.

\section{References}

Belaj, Branimir. 2005. On the cognitive status of mental spaces and of some types of metonymy within Conceptual Integration Theory. Jezikoslovlje 6(2). 119-144.

Berninger, Mark \& Ecke, Jochen \& Haberkorn, Gideon. 2010. Introduction. In Berninger, Mark \& Ecke, Jochen \& Haberkorn, Gideon (eds), Comics as nexus of cultures: Essays on the interplay of media, disciplines and international perspectives, 1-4. Jefferson, North Carolina: McFarland \& Company.

Castaldi, Simone. 2010. Drawn and dangerous: Italian comics of the 1970s and 1980s. Jackson: University Press of Mississippi. http://dx.doi.org/10.14325/mississippi/9781604737493.001.0001

Cohn, Neil. 2013. The visual language of comics: Introduction to the structure and cognition of sequential images. London: Bloomsbury. 
Evans, Vyvyan \& Green, Melanie. 2006. Cognitive linguistics: An introduction. Edinburgh: Edinburgh University Press. https://doi.org/10.4324/9781315864327

Fauconnier, Gilles. 1997. Mappings in thought and language. Cambridge: Cambridge University Press. http://dx.doi.org/10.1017/CBO9781139174220

Fauconnier, Gilles \& Turner, Mark. 1998. Conceptual integration networks. Cognitive Science 22(2). 133-187. http://dx.doi.org/10.1207/s15516709cog2202_1

Fauconnier, Gilles \& Turner, Mark. 1999. Metonymy and conceptual integration. In Panther, Klaus-Uwe \& Radden, Günther (eds.), Metonymy in language and thought, 77-90. Amsterdam: John Benjamins. https://doi.org/10.1075/hcp.4.05fau

Fauconnier, Gilles \& Turner, Mark. 2002. The way we think. New York: Basic Books.

Forceville, Charles. 2003. Visual representations of the idealized cognitive model of anger in the Asterix album La Zizanie. Journal of Pragmatics 37. 69-88. https://doi.org/10.1016/j.pragma.2003.10.002

Forceville, Charles. 2009. Creative visual duality in comics balloons. In Veale, Tony \& Feyaerts, Kurt, \& Forceville, Charles (eds.), Creativity and the agile mind: A multidisciplinary study of a multi-faceted phenomenon, 253-272. Berlin: Mouton de Gruyter. http://dx.doi.org/10.1515/9783110295290.253

Forceville, Charles \& Urios-Aparisi, Eduardo (eds.). 2009. Multimodal metaphor. Berlin: Mouton de Gruyter. http://dx.doi.org/10.1515/9783110215366

Lakoff, George \& Turner, Mark. 1989. More than cool reason: A field guide to poetic metaphor. Chicago: University of Chicago Press. http://dx.doi.org/10.7208/chicago/9780226470986.001.0001

Matovac, Darko \& Tanacković Faletar, Goran. 2009. TCM i CIT - dvije suprotstavljene teorije ili krajnje točke istoga procesa? Jezikoslovlje 10(2). 133-151.

McCloud, Scott. 1993. Understanding comics. New York: Harper Perennial.

Potsch, Elisabeth \& Williams, Robert F. 2012. Image schemas and conceptual metaphor in action comics. In Bramlett, Frank (ed.), Linguistics and the study of comics, 13-36. New York: Palgrave MacMillan. http://dx.doi.org/10.1057/9781137004109_2

Saraceni, Marco. 2003. The Language of comics. London: Routledge.

Somov, Georgij Yu. 2013. The interrelation of metaphors and metonymies in sign systems of visual art: An example analysis of works by V.I. Surikov. Semiotica 193. 31-66. http://dx.doi.org/10.1515/sem-2013-0003

Stanojević, Mateusz-Milan. 2009. Konceptualna metafora u kognitivnoj lingvistici: pregled pojmova. Suvremena lingvistika 68. 339-369.

Veale, Tony \& Feyaerts, Kurt \& Forceville, Charles. 2009. E Unis Pluribum: Using mental agility to achieve creative duality in word, image, and sound. In Veale, Tony \& Feyaerts, Kurt \& Forceville, Charles (eds.), Creativity and the agile mind: A multidisciplinary study of a multi-faceted phenomenon, 37-57. Berlin: Mouton de Gruyter. http://dx.doi.org/10.1515/9783110295290.37 
Wilkins, Peter. 2015. An incomplete project: graphic adaptations of Moby-Dick and the ethics of response. In Grennan, Simon \& Grove, Laurence (eds.), Transforming Anthony Trollope: Dispossession, Victorianism and nineteenth-century word and image, 217233. Leuven: Leuven University Press.

Wolk, Douglas. 2007. Reading comics: How graphic novels work and what they mean. Philadelphia: Da Capo Press.

\section{Web sources}

http://en.sergiobonelli.it/section/2569/dyd-s-world (last accessed on September 27, 2019) https://hudsonreview.com/2013/02/villons-epitaph-ballade-of-the-hanged-men/(last accessed on September 27, 2019)

\section{Author's address:}

Ilhana Škrgić

Ibrahima Mržljaka 56

77230 Velika Kladuša

Bosnia and Herzegovina

ilhana.skrgic@bih.net.ba

\section{FIGURATIVNO PREDSTAVLJANJE SMRTI U TALIJANSKOM STRIPU DYLAN DOG}

Tradicionalno predstavljanje smrti kao Sablasnog kosca poznat je trop u umjetnosti. Glavni je cilj ovog rada analiza ovog tropa u izabranim izdanjima talijanskog stripa Dylan Dog. Fauconnier i Turner iscrpno su razmatrali njegovu kompleksnost opisivajući ga uz pomoć modela teorije blenda/konceptualne teorije integracije. Kao kompleksna integracija nekoliko mentalnih prostora, uključujući prostor smrti individualnog ljudskog bića, te prostora žetve, blend "Sablasnog kosca" ("The Grim Reaper") uključuje metaforičke i metonimijske integracije neistovjetnih elemenata (Fauconnier i Turner 1998). Ovaj model bit će korišten kao početna točka u analizi korpusa koji se sastoji od četiri različite priče Dylana Doga. U izabranim izdanjima, Sablasni se kosac pojavljuje u tradicionalnoj verziji: stvorenje nalik na kostura obučeno u redovničku halju koje drži kòsu, kao i u varijantama u kojima njegov izgled dobiva nove i neobične karakteristike. Bit će prikazano kako upotreba medija stripa od strane umjetnika, uz pomoć kombinacije pisanog teksta i statičkih vizualnih elemenata, omogućava određene kreativne varijante klasičnog tropa.

Ključne riječi: metafora; metonimija; blend; Smrt; Dylan Dog; stripovi; grafičke novele. 